\title{
Legal Protection of Land Tenure by Foreign Investors through Nominee Agreement in Bali, Indonesia
}

\author{
Simon Nahak ${ }^{*}$ and I Nyoman Putu Budiartha
}

Warmadewa University, Bali, Indonesia

\begin{abstract}
This paper aims to describe legal protection as the provision of legal certainty to every citizen, individual or legal entity, to fight for and/or defend their rights and obligations by law enforcement officers and/or authorized officials in a certain place. More specifically, the analysis was conducted by using the socio-legal approach to examine the legal protection of land tenure by foreign investors through the nominee agreement in Bali, Indonesia. Moreover, the method was also done by using a normative approach through the analysis of legal matters in Indonesian laws. The legal basis is regulated in the basic constitutional provisions of the 1945 Constitution of the Republic of Indonesia, the Criminal Code, the Civil Code, the Basic Agrarian Law, the Environmental Act, Tourism Act, Investment Act, Government Regulation No. 41 of 1996 concerning ownership of residential houses or dwellings by foreigners domiciled in Indonesia. The results showed that there is no exception to foreign investors who contribute to the community also get legal protection. To carry out these investment activities requires land that is sometimes controlled by using nominee. The nominee is someone who acts for and on behalf of another party as the endorsee/guardian, agent/representative of the nominee/simulation/fake agreement. Sociological outlook showed that the sociological basis of Balinese society consists of a spiritual community that upholds local culture because many foreign citizens visit and reside because they want to take a vacation to visit the tourist area and find work in Bali, especially working in the field of tourism services and other fields of work that revive the community in Bali.
\end{abstract}

Keywords: Legal protection, foreign investors, nominee, tourism environment.

\section{INTRODUCTION}

Land in the history of human civilization in Bali is the most important factor in determining the production of each phase of civilization. Because land in Bali is not only economical but also has a supernatural relationship with humanity. Because besides Land has a high economic value, also philosophical, political, social, and cultural values, as well as a place to praise God and especially as an heir (purusa). Keraf (1998) stated that land is a natural resource that is needed by humans, where human needs for land are always increasing, and land availability is limited. Because of the limited land, the impact on the economic value is higher because it is based on the increasing demand for land, so that the actual land for human habitation is shifted into business goods that lead to very fierce competition. Soemitro (1970) stated that land becomes a special treasure that incessantly triggers various problems in society, especially in Bali and in Indonesia in general. The expert opinion description emphasizes that all activities including investing must require land which in its possession takes into account environmental impacts that have or will occur in the future. It can be realized that the Republic of Indonesia is a state of law so all activities of Indonesian citizens must be based on law, but law problems often occur

\footnotetext{
*Address correspondence to this author at the Warmadewa University, Bali, Jl. Terompong No. 24, Tanjung Bungkak, Denpasar, Bali 80235, Indonesia; Tel: (0361) 223858, 081547397113; Fax: (0361) 235073;

E-mail: simonahak.warmadewa@gmail.com
}

when the activity is carried out as if there is still a blurred legal basis (Juwono, 2013; Sihombing, 2019).

In term of legal protection and regulations for parties involved in the land tenure process by foreign investors through a nominee agreement in Bali, the party involved in the process of land acquisition by foreign investors is a notary public official who is authorized to issue a sale and purchase, lease, and investment contract agreement. Landowners, related institutions, in this case, the National Land Agency, Investment Board, foreign investors, the Directorate General of Taxation, must receive legal protection with certain arrangements so that they are treated equally before the law based on the principle of equality (Budiartha \& Puspadma, 2019; Budiartha, 2019; Budiartha, 2018; Budiartha, 2018).

Hence, the study has the scope of legal issues with research formulations being to analyse the legal protection and arrangement for the parties involved in the process of land acquisition by foreign investors through a nominee agreement in the tourism area of Bali. By using the research method used of juridicalnormative research, with a philosophical approach, a concept approach, a statutory approach, the study also investigates the legal effort for the abuse of land ownership by foreign investors through nominee agreements in Bali. This paper aims to analyze the legal protection is the provision of legal certainty to every citizen, individual or legal entity, to fight for and/or defend their rights and obligations by law 
enforcement officers and/or authorized officials in a certain place. More specifically, the analysis was conducted by using the socio-legal approach to examine the legal protection of land tenure by foreign investors through the nominee agreement in Bali, Indonesia.

\section{LITERATURE REVIEW}

The tourism environment and cultural richness in Bali that developed rapidly in the current era of globalization, many foreign citizens are interested in living and investing in these thousand temples island(BKPMD, 2013). The rapid development of investment, the attractiveness of the island of Bali in bringing in investment by foreign investors, and the desire to have a residence by foreign citizens are in line with the benefits and results obtained in the form of an increase in the economy on the island of Bali. Then the regulation of the use of land to build investment facilities must be based on the conception of the state's right to control land and other conceptions contained or adhered to by the Basic Agrarian Law (BAL), namely the principle of nationality. A principle that only gives rights to Indonesian citizens who can own land rights.

Article 21 paragraph (1) of the Basic Agrarian Law adheres to the national principle determining that only Indonesian citizens can have ownership rights. It is clearly stated that only Indonesian citizens can have a full relationship with the land as part of the land as contained in the provisions of article 9 paragraph (1) of the Basic Agrarian Law, then the implementation is an attempt to realize the phrase contained in the provisions of article 33 paragraph (3) amendment IV of the 1945 Constitution of the Republic of Indonesia. Article 26 paragraph (2) of the Basic Agrarian Law stipulates that every sale, exchange, a gift, a gift with the will, and other acts intended to directly or indirectly transfer ownership rights to a foreigner, to a citizen who besides his Indonesian citizenship has a foreign nationality or to a legal entity except those stipulated by the government referred to in article 21 paragraph (2), is null and void by law and the land falls to the state. Provided that other rights that burden him continue and all payments that have been received by the owner cannot be claimed again. The Nominee Agreement is categorized as one form of the nominee agreement because there is no specific regulation and it is not explicitly mentioned in the articles of the Civil Code, the Criminal Code, the Basic Agrarian Law, the Investment Law, and the Taxation Law. The nominee is someone who acts to name another party as a representative in the limited narrow sense. Sometimes the term is used to signify as an agent or guardian (Garner, 1999).

Article 1320 of the Civil Code determines if an agreement is contrary to objective conditions so that any form of the agreement made, the agreement between the Foreign Investor and the Nominee of an Indonesian citizen, is invalid and null and void under the law. Besides that, as stipulated in article 1335 of the Civil Code, an agreement without a cause, or that has been made for some reason, which is false or forbidden, has no power, this article reiterates one of the objective conditions of the validity of the agreement.

The nominee agreement since its birth has had the character of being against the law which when viewed from a civil perspective. Judging from the aspect of criminal law in the field of taxation is that there are conditions that cause the subject of the taxpayer not to pay the tax that should be paid by the subject of the taxpayer, so it is very clear that there is a tax crime that is occurred. Because with the nominee agreement, the tax liability of foreign investors towards the transfer of land rights is carried out by Indonesian citizens, there is tax avoidance in the form of a transaction scheme that minimizes the tax obligations of foreign nationals. Indonesian taxation criminal law has criminal sanctions and fines due to intentional elements (dolus) and negligence (culpa), as evidenced by inner intentions (men's rea) and physical actions that are evil directly (actus reus).

The nominee Agreement is categorized as one form of the innominaatagreement because there is no specific regulation concerning it and it is not explicitly mentioned in the articles of the Civil Code in Indonesia. Implicitly, a nominee agreement has the elements as an agreement between two parties, namely the beneficial owner as of the authorizer and the nominee as the endorsee, based on the trust and beneficial owner to the nominee. In this agreement, the power of attorney is special with limited types of legal action and nominees act as if they are representatives of a beneficial owner before the law.

The debt and credit agreement which makes the land in the name of the Indonesian citizen as collateral is one of the agreements in a single nominee agreement. Land that is pledged as collateral is the land with the status of ownership rights, which are then burdened with mortgage rights on behalf of foreign nationals. As a guarantee, the foreign citizen will hold 
the mortgage deed issued in his name. After continuing with the making of power of attorney to grant power of attorney with substitution rights to foreign citizens to represent and act on behalf of the Indonesian citizens to take care of all matters, pay attention to their interests, and represent the rights of the granting authority rent out and administer building permit (Wahanisa et al., 2019), sign a tax notice and other necessary documents, as well as making authorization to use the land for development purposes in accordance with the construction permit and building use permit, for residential or business premises (Purba, 2006).

The discussion in this sub-section is analyzed by the theory of legal norm selection (stufenbou theory) that is according to Hans Kelsen (1967) in his general theory of law and state, Pure Theory of Law, concerning positive and negative regulations; commanding, authorizing, permitting and the hierarchical structure of the legal order, elaborates on positive law that must be separated from moral, economic, social and cultural, as well as positive and negative regulations: ordering, authorizing, allowing and hierarchical structure of the legal order. The theory is used to analyze norm conflicts between nominee agreements made before a notary and the provisions of the Civil Code.

Tanya et al. (2010) stated that law is normative because the value of justice is the crown of every legal system. The value of justice is the material that becomes the content of the law that must be protected by its rules. The law has three aspects namely; justice, expediency, and certainty. Tanya et al. (2010) stated that if there is a conflict between the rule of law in all three aspects and justice becomes so great that it truly feels unfair, then for the sake of justice the law is released. John Rawls (2009) explained that justice is closely related to the distribution of rights and obligations. Justice, in general, is a condition where everyone who gets what is rightfully his and every person gets the same part of the shared wealth. This form of legal protection must even be implemented against foreign investors who use land that uses nominees in the tourism environment because each investor is obliged to comply with statutory provisions to deposit the initial capital of a business which is a sum of capital, both in the form of money and labor (ability or the skills a person has to run a business in a company) are needed and will be used to start a business for the first time in a company.

\section{RESEARCH METHOD}

The research was conducted with the purpose to analyse the legal protection in the provision of legal certainty to every citizen, individual or legal entity, to fight for and/or defend their rights and obligations by law enforcement officers and/or authorized officials in a certain place. To achieve this purpose, the study used the socio-legal approach and normative-juridical method. The motivation of the socio-legal approach is the sociological perspective in legal matters that there is no exception to foreign investors who contribute to the community also gets legal protection. To carry out these investment activities in Indonesia requires land that is sometimes controlled by using nominee.

The normative-juridical method was conducted by exploring some regulations used as a basis for analysis. The existing regulations and laws used include Article 24 and Article 25 of Act Number 12 of 1994 concerning Amendment of Act Number 12 of 1985 concerning Land and Building Tax for submitting a Tax Object Notification, but the contents are incorrect or complete and/or attach an incorrect statement. Moreover, by using the criminal justice process, the analysis requires several related documents in proving the existence of criminal allegations in Article 24, Article 25 of the United Nations Code (UN Code), Article 263, and Article 266 of the Criminal Code. Since making the police report, if there is already sufficient initial strong evidence of the occurrence of a tax crime, as referred to in Article 24, Article 25 of the UN Code, Article 263, and Article 266 of the Criminal Code, it also has relevance to the provisions of article 102 paragraph (1) and Article 106 of Act No. 8 of 1981 concerning the Criminal Procedure Code and Article 102 paragraph (1) of the Criminal Procedure Code.

\section{RESULTS AND DISCUSSION}

The results showed the legal effort against abuse of land ownership by the foreign citizen through nominee agreements in Bali. The obscurity of the law gives rise to different interpretations of the three parties involved, namely, an Indonesian citizen who is a nominee, a foreign citizen, and also a notary who makes the nominee agreement along with other deeds that cause legal conflicts until it ends in court. The notary public officer who made the nominee agreement will postulate that following Article 1 of the Law of the Republic of Indonesia Number 30 of 2004 concerning the Position of Notary and article 1868 of the Civil Code. The task of the notary is to make authentic deeds that can be in the 
form of a deed of agreement in the form of leases, accounts payable, and other agreements. The notary in carrying out his/her official duties only formulates the wishes or actions of the parties in an authentic deed and concludes the legal relations of the parties in written form and certain format to realize the legal relationship between legal subjects that are civil.

Different interpretations create a high potential for conflicts and civil and criminal law issues that originate in the nominee agreement including the criminal aspects involved in the nominee agreement against foreign nationals who control ownership of land rights using the names of Indonesian citizens. The issues are crimes against land grabbing are regulated in Article 167 of the Criminal Code, crimes against perjury and false information are regulated in article 242 of the Criminal Code, crimes against falsification of documents are regulated in article 263, article 264, falsification of letters, article 266, order to insert false information into an authentic deed regulated in article 274 of the Criminal Code, the crime of forgery of a certificate, embezzlement of the rights to immovable property, such as land, rice fields called stallion at crime regulated in Article 385 of the Criminal Code, intentionally and negligently avoiding or embezzling taxes as regulated in Article 38, 39 of RI Act No. 28 of 2007 concerning General Provisions and Procedures for Taxation and Article 24, 25 of the Act of the Republic of Indonesia Number 12 of 1994 concerning Land and Building Tax.

In addition to adhering to a religious communalistic conception that allows individual land tenure, the Basic Agrarian Law also adheres to the principle of Nationality. This principle of nationality is contained in article 21 paragraph (1) of the Basic Agrarian Law which states that only Indonesian citizens can have ownership rights. In this case, only Indonesian citizens can have a full relationship with the land as part of the earth as contained in the provisions of article 9 paragraph (1) of the Basic Agrarian Law. The implementation is an attempt to realize the phrase contained in the provisions of article 33 paragraph (3) amendment IV of the 1945 Constitution of the Republic of Indonesia. The relationship referred to in this case is a manifestation of the rights of ownership.

The process of lawsuits in the event of a legal problem is to enter into an agreement that is contrary to positive law (due to lawful reasons). The threat of punishment is in the form of civil punishment that is giving compensation for losses caused to the sufferer.
Criminally, prosecutors should be given a sentence of imprisonment because they have fulfilled the elements of the articles alleged and have been legally proven to have committed crimes in the field of taxation as stated in Article 24 and Article 25 of Act Number 12 of 1994 concerning Amendment of Act Number 12 of 1985 concerning Land and Building Tax for submitting a Tax Object Notification, but the contents are incorrect or complete and/or attach an incorrect statement.

The criminal justice process requires several related documents in proving the existence of criminal allegations in Article 24, Article 25 of the United Nations Code (UN Code), Article 263, and Article 266 of the Criminal Code. Since making the police report, if there is already sufficient initial strong evidence of the occurrence of a tax crime, as referred to in Article 24, Article 25 of the UN Code, Article 263, and Article 266 of the Criminal Code, it also has relevance to the provisions of article 102 paragraph (1) and Article 106 of Act No. 8 of 1981 concerning the Criminal Procedure Code. Article 102 paragraph (1) of the Criminal Procedure Code determines that investigators who know, receive reports, or complaints about the occurrence of an event that is reasonably suspected of being a criminal offense must immediately conduct the necessary investigative actions. Article 106 of the Criminal Procedure Code determines that investigators who are aware of, receive reports or complaints about the occurrence of an event that is reasonably suspected of being a criminal offense must immediately conduct the necessary investigative actions.

Hence, it needs to identifying indigenous lands, tribes/communal land, inheritance, ownership rights, cultivation rights, building rights, use rights, lease rights, land opening rights, rights to collect forest products; seeking certification of customary, tribal/communal land rights, inheritance or ownership right and/or non-certified land rights; and developing the concept of leasing by sharing production contracts on customary land, tribal/communal land, inheritance and ownership rights, cultivation rights, building rights, use rights, lease rights, rights to open land, the right to collect forest products (Nahak, 2019)

Legal effort carried out by parties who feel aggrieved by those who abuse land control by foreign citizens in Bali are through non-legal/non-litigation efforts in the form of mediation outside the court and litigation efforts in the form of civil law, state administrative law by filing a civil lawsuit/state administration to the local district court/state 
administrative court, appeal legal efforts through the High Court and appeal to the Supreme Court. If the attempt to Civil Law and Administration and the state does not succeed it will be the last legal effort that through the efforts of criminal law in the criminal justice system in force in Indonesia, which is by making a report to the police, the prosecutor and the district court, high court and the supreme court as a general legal effort to extraordinary legal effort to take legal actions reconsideration.

The results support the previous literature demonstrating the importance of the improvement in land law in Indonesia to support foreign investment as well as to ensure the legal certainty about land rights in Indonesia (Reerink \& Van Gelder, 2010; Agrawal, 1999; Rajenthran, 2002; McCarthy \& Robinson, 2016). It also denoted the importance of spatial planning in Indonesia, especially in tourism areas, to support environmental sustainability and economic interest (Wardana, 2015; Taleshi \& Bisheii, 2015; Hudalah et al., 2016; Wijaya et al., 2012).

Legal protection and arrangements for parties involved in the process of land acquisition by foreign investors through a nominee agreement in the area of tourism in the province of Bali involving several parties, including the notary as the acting officer for land deed (PPAT), landowners, investors, regency/city national land office, provinces and even the directorate general of land, business license providers to investors as domestic/foreign investment. Investors get legal protection in the form of setting up the formation of laws and regulations that regulate exactly business activities using nominees. Related to the nominee, there is no definitive regulation so that so far, the business practices of using nominees have unclear legal norms, so Indonesia prohibits the nominee agreement. Land ownership by Indonesian citizens for foreign investors can be through the concept of identifying customary, tribal/communal lands, inheritance, ownership rights, business rights, cultivation rights, building rights, lease rights, right to open land, right to collect forest products. Another way is to seek certification of customary, tribal/communal land rights, inheritance, and other land rights and/or rights that have not yet been certified. Another way is to develop the concept of leasing by sharing production contracts for customary land, tribal/communal land, inheritance, ownership rights, business rights, cultivation rights, building rights, lease rights, right to open land, right to collect forest products.

\section{CONCLUSION}

The results showed that in terms of legal effort against misappropriation of land by foreign investors through a nominee agreement in Bali, the legal effort is taken against the abuse of land tenure by foreign investors through nominee agreements namely nonlitigation through mediation, international arbitration, and litigation through civil laws in district courts, claims for cancellation of certificates. If there is an error in the process of issuing the certificate, this can be submitted to the state administrative court. In the event of a commercial dispute, a request to the commercial court and criminal legal remedy through the criminal justice system both through the police, attorney general's office, and the district court to the supreme court and an extraordinary legal remedy namely through judicial review can be submitted.

Legal protection and regulations for parties involved in the land tenure process by foreign investors through a nominee agreement in the Bali provincial tourism environment zone, investors should get the legal protection that provides legal certainty for justice. However, because it is related to investor's business activities using land through the use of nominee, it has not been explicitly and surely regulated in the provisions of the Civil Code, the Criminal Code, the Basic Agrarian Law, and the Investment Law, so it should be necessary to formulate political politics as regulated in the Civil Code, Criminal Code, Basic Agrarian Law, Investment Act. It needs to be regulated in the nominee Act separately into a Special Act on Nominee. Investors should use the right to use, the right to use the building, the right to lease, the right to use the business or sharing production so that they do not suffer losses because the right of ownership of land is only owned by Indonesian citizens. To convince investors who conduct business activities in Bali when there is an abuse of land tenure by foreign investors through nominee agreements in Bali, it should be handled both non-litigation and litigation by upholding the principle of justice which is fast, simple, and low cost.

\section{ACKNOWLEDGEMENT}

Researchers would like to thank the Postgraduate Director of Warmadewa University for funding this research, transportation costs, accommodation going from Bali to Tokyo to be able to present research internationally at Niigata University, Tokyo, Japan. 


\section{REFERENCES}

Agrawal, P. (1999). Urban land consolidation: a review of policy and procedures in Indonesia and other Asian countries. GeoJournal, 49(3), 311-322. https://doi.org/10.1023/A:1007150828772

BKPMD/Bali Regional Investment Coordinating Board. (2013). InvestasiPenanaman Modal Asing di Bali Lampaui Target. Retrieved from http://selebzone.com/bkpmd-investasipenanaman-modal-asing-di-bali-lampaui-target.html

Budiartha, I. (2018). Work Permit for Foreign Workers in Indonesia. Journal of Legal, Ethical and Regulatory Issues, 21(SI).

Budiartha, I. N. P. (2019). The Existence of Pancasila as a Basic Rule toward the Dispute Settlement of Complaint Offence through Penal Mediation outside the Court of Indonesia. Journal of Legal, Ethical and Regulatory Issues, 22(2), 1-5.

Budiartha, I. N. P., \&Puspadma, I. N. A. (2019). Income Tax in the Issuing of Authentic Deed of Sale-Purchase Rights on Land by Land Deed Officer in Indonesia. Journal of Legal, Ethical and Regulatory Issues.

Budiartha, N. P. (2018). Restriction and incentives of investment in Indonesia: Considering the provisions of basic agrarian law and capital market law. European Research Studies Journal 21 (2), 178-188. https://doi.org/10.35808/ersj/993

Garner, B. A. (1999). Black's Law Dictionary With Guide to Pronunciation. St. Paul: West Publishing,

Hudalah, D., Rahmat, Y. N., \& Firman, T. (2016). 8 Housing low-and middle-income households: land development and policy practice in two Indonesian cities. Land and Development in Indonesia: Searching for the People's Sovereignty, 186. https://doi.org/10.1355/9789814762106-013

Juwono, H. (2013). Antara bezitsrecht dan eigendomrecht: kajiantentanghakatastanah oleh penduduk. Jurnal Hukum dan Peradilan, 2(1), 131-150. https://doi.org/10.25216/JHP.2.1.2013.131-150

Kelsen, H. (1967). Pure theory of law. Univ of California Press.

Keraf, A. S. (1998). Business Ethics (Demands and Relevance). Jakarta: Kanisius.

McCarthy, J. F., \& Robinson, K. (Eds.). (2016). Land and development in Indonesia: searching for the people's sovereignty. ISEAS-Yusof Ishak Institute. https://doi.org/10.1355/9789814762106

Nahak, S. (2019). Implikasi Hukum Pertanahan Terhadap Pemindahan Ibu Kota Negara Republik Indonesia Dari
Jakarta Ke Kalimantan Timur. Ganaya: Jurnal IImuSosial Dan Humaniora, 2(2-2), 31-40.

Purba, N. C. (2006). KeabsahanPerjanjianInnominaatDalamBentuk Nominee Agreement (AnalisisKepemilikan Tanah oleh Warga Negara Asing) (Doctoral dissertation, Tesis, FakultasHukumUniversitas Indonesia, Depok).

Rajenthran, A. (2002). Indonesia: An overview of the legal framework for foreign direct investment. ISEAS.

Rawls, J. (2009). A theory of justice. Harvard university press. https://doi.org/10.2307/j.ctvkib25m

Reerink, G., \& Van Gelder, J. L. (2010). Land titling, perceived tenure security, and housing consolidation in the kampongs of Bandung, Indonesia. Habitat International, 34(1), 78-85. https://doi.org/10.1016/j.habitatint.2009.07.002

Sihombing, B. F. (2019). Contemporary issues of agrarian law institutions: Critical analysis of legal structure on human capital and information technology. Journal of Legal, Ethical and Regulatory Issues, 22(2), 1-11.

Soemitro, R. H. (1990). Legal and Jurimetry Research Methods. Jakarta, Ghalia Indonesia.

Suparji, S. (2020). Politics of Legal in Nominee Agreement And Its Practice In Indonesia. Journal of Advanced Research in Law and Economics, 11(1), 196-202. https://doi.org/10.14505//jarle.v11.1(47).23

Taleshi, M., \& Bisheii, S. (2015). Spatial Planning Approach: An Efficient Pattern for Accessing Territorial Sustainable Development. Case Study: European Spatial Planning. OIDA International Journal of Sustainable Development, 8(10), 3742

Tanya, B. L., Simanjuntak, Y. N., \& Hage, M. Y. (2010). Teori Hukum Strategi Tertib Manusia Lintas Ruang dan Generasi. Yogyakarta: Genta Publishing.

Wahanisa, R., Hidayat, A., \& Anggono, B. D. (2019). The Nuisance Ordinance in the Establishment of Commercial Buildings and Legal Enforcement of Spatial Planning at the Regional Government Level. Journal of Legal, Ethical and Regulatory Issues, 22(6), 1-7.

Wardana, A. (2015). Debating spatial governance in the pluralistic institutional and legal setting of Bali. The Asia Pacific Journal of Anthropology, 16(2), 106-122. https://doi.org/10.1080/14442213.2014.997276

Wijaya, I. N. S., Yoshitake, T., \& Deguchi, C. (2012). Practical Constraint of Indonesian Municipalities in Conducting the Urban Land Use Assessment. European Journal of Social Sciences, 31(1), 42-57.

\begin{tabular}{ll}
\hline Received on 14-01-2021 & Accepted on 25-02-2021
\end{tabular}

Published on 03-03-2021

\section{https://doi.org/10.6000/1929-4409.2021.10.68}

(C) 2021 Nahak and Budiartha; Licensee Lifescience Global.

This is an open access article licensed under the terms of the Creative Commons Attribution Non-Commercial License (http://creativecommons.org/licenses/by-nc/3.0/) which permits unrestricted, non-commercial use, distribution and reproduction in any medium, provided the work is properly cited. 